\title{
HUBUNGAN AKTIVITAS FISIK DENGAN KEBAHAGIAAN PADA MASA PANDEMI COVID-19
}

Nesi

nesiaureole@gmail.com, Politeknik Kesehatan Hermina

\begin{abstract}
The covid-19 pandemic causes changes in daily activities so that a person limits their activities. This is considered to have an effect on a person's mood. Objective: To investigate the relationship between physical activity and happiness in young adults during the covid-19 pandemic. Methods: This study used a cross-sectional study method. Data was collected through a google form containing a demographic questionnaire, the International Physical Activity Questionnaire (IPAQ) and the Subjective Happiness Scale (SHS). Results: there are differences in happiness based on the level of physical activity, someone with the highest level of physical activity shows the greatest happiness. However, no significant difference has been found between the share and the level of physical activity.
\end{abstract}

Keywords: physical activity, happiness, young adults, covid-19

\begin{abstract}
Abstrak
Pandemi covid-19 menyebabkan terjadinya perubahan dalam kegaiatan sehari-hari sehingga seseorang membatasi dirinya untuk beraktivitas. Hal ini dianggap berpengaruh terhadap suasana hati seseorang. Tujuan penelitian ini menyelidiki hubungan antara aktivitas fisik dengan kebahagiaan pada dewasa muda selama pandemic covid-19. Metode penelitian ini menggunakan metode cross-sectional study. Data dikumpulkan melalui google form yang berisi kuesioner demografis, International Physical Activity Questionnaire (IPAQ) dan Subjective Happiness Scale (SHS). Hasil penelitian terdapat perbedan kebahagiaan berdasarkan tingkat aktivitas fisik, seseorang dengan tingkat tingkat aktivitas fisik paling tinggi menunjukan kebahagiaan paling besar. Meskipun demikian belum ditemukan perbedaan signifikan antara kebahagian dan tingkat aktivitas fisik.
\end{abstract}

Kata Kunci: aktivitas fisik, kebahagiaan, dewasa muda, covid-19

\section{PENDAHULUAN}

Pandemi covid-19 terjadi di seluruh dunia sejak Januari 2020. Untuk mengendalikan penyebaran virus covid-19, Pemerintah Indonesia mengeluarkan peraturan PPKM berlevel yang bertujuan untuk memutus rantai penularan infeksi covid-19. Hal ini tentu saja berimbas ke berbagai aktivitas seperti kegiatan perkantoran, pendidikan, perekonomian. keagamaan dan kegiatan sosial.

Dalam menghadapi covid-19, masyarakat dihimbau meningkatkan imunitas. Salah satu cara meningkatkan imunitas adalah dengan meningkatkan kebahagiaan. Kebahagiaan didefinisikan sebagai kondisi psikologis yang positif, yang ditandai oleh tingginya kepuasan terhadap masa lalu, tingginya tingkat emosi positif, dan rendahnya tingkat emosi negatif (Carr dalam Astuti, 2007). Hidup bahagia sering digambarkan sebagai kehidupan yang indah, penuh dengan antusiasme dan gairah. Perasaan bahagia pada setiap orang akan berbeda berdasarkan hasil dari interpretasi mereka masing-masing yang dipengaruhi oleh nilai-nilai budaya (Hamka, 2015). 
Kebahagiaan memberikan banyak manfaat dalam kehidupan baik dari segi kesehatan, mengurangi stress, dan peningkatan prestasi. Penelitian yang dilakukan Marsland et al (2006) menunjukan bahwa seorang yang berbagia menunjukan sistem kekebalan tubuh yang kuat, kesehatan yang lebih baik, dan kemampuan untuk melawan infeksi atau penyakit dengan lebih efektif. Steptoe (2008) mengemukakan bahwa individu yang lebih bahagia secara konsisten menurunkan kadar kortisol atau hormone stress dalam darah mereka. Brockis (2019) dalam penelitiannya menemukan korelasi positif antara kebahagiaan dan kemampuan berpikir dalam menyelesaikan masalah. Hal ini disebakan karena seseorang yang bahagia akan menjukkan pribadi yang memiliki keharmonisan sosial, memperoleh personal achievement dan self esteem yang tinggi (Hamka, 2012). Hal tersebut menyebabkan pentingnya kebahagiaan dalam kehidupan, terutama dewasa muda di masa pandemi covid-19. Untuk itu peneliti berupaya menemukan solusi sederhana dalam meningkatkan kebahagiaan dewasa muda selama pandemic covid-19. Salah satu upaya yang dapat dilakukan yaitu dengan aktivitas fisik.

Menurut Kementerian Kesehatan Republik Indonesia mengartikan aktivitas fisik sebagai setiap gerakan tubuh yang diakibatkan kerja otot rangka dan meningkatkan pengeluaran tenaga serta energi. Aktivitas fisik mengacu pada semua aktivitas yang dilakukan termasuk selama waktu senggang, selama bepergian ke tempat kerja, atau aktivitas pekerjaan seseorang (WHO). Aktivitas fisik contohnya berjalan, berlari, menari, berenang, yoga, dan berkebun adalah beberapa contoh aktivitas fisik.

Penelitian-penelitian sebelumnya menemukan korelasi antara aktivitas fisik dengan kebahagiaan (Pool, 2014; Nejadghani, 2017; Eoudenberg, 2020 ). Penelitian yang dilakukan oleh Pool (2014) menemukan efek positif antara aktivitas fisik dengan kebahagiaan pada lansia. Penelitian yang dilakukan Nejadghani (2017) menemukan efek psikologis aktivitas fisik terhadap kebahagiaan tergantung dari kepribadian individu tersebut, dalam hal ini kepribadian extravertion menunjukan efek paling tinggi dan efek paling rendah pada orang dengan kepribadian neurosis. Penelitian yang dilakukan Eoudenberg dkk (2020) menemukan adanya korelasi timbal balik antara kebahagiaan dengan aktivitas fisik pada remaja, kebahagiaan meningkatkan minat melakukan aktivitas fisik dan aktivitas fisik meningkatkan mood bahagia.

Meskipun demikian belum banyak penelitian yang dilakukan dengan mengunakan partisipan dewasa muda terutama selama pandemi covid-19, sehingga penting dilakukan penelitian untuk melihat hubungan antara aktivitas fisik dengan kebahagiaan pada dewasa muda selama pandemi covid-19.

\section{METODE}

Penelitian ini bertujuan untuk mengetahui bagaimana tingkat aktivitas fisik dan kebahagiaan pada masa pandemi covid-19. Selanjutnya, penelitian ini dilakukan untuk melihat hubungan antara aktivitas fisik dengan kebahagiaan. Variabel independen pada penelitian ini yaitu aktivitas fisik, sedangkan variabel dependen yaitu kebahagiaan. Penelitian ini menggunakan metode cross-sectional study. Partisipan penelitian diminta memberikan self report, sehingga pengukuran hanya berdasarkan persepsi dari partisipan.

\section{Partisipan}

Pengambilan sampel dilakukan dengan teknik total sampling yaitu semua partisipan yang melengkapi semua jawaban kuesioner dan sesuai kriteria usia yaitu dewasa muda dimasukan ke dalam partisipan. Total partisipan yang berpartisipasi dan datanya dapat diolah dalam penelitian 
ini adalah 115 partisipan dewasa muda yang berusia $17-27$ tahun $(\mathrm{M}=21.17, \mathrm{SD}=4.230)$ yang berdomisili di daerah Jakarta. Partisipan dalam penelitian ini terdiri dari 88 perempuan $(76.5 \%)$ dan 27 laki-laki (23.5\%).

\section{Instrumen}

Kuesioner demografi sosial. Kuesioner ini berisi informasi partisipan mengenai usia, jenis kelamin, profesi, tinggi badan dan berat badan.

International Physical Activity Questionnaire (IPAQ)

Kuesioner ini berisi 27 butir pertanyaan mengenai durasi aktifitas fisik yang dilakukan selama tujuh hari terakhir. Hasil dari kuesioner tersebut dikategorikan menjadi tiga tingkat aktivitas fisik yaitu hepa active, minimaly active, inactive. Dikategorikan hepa active apabila seseorang melakukan aktifitas fisik intensitas berat paling sedikit tiga hari dan mencapai 1500 MET-menit/minggu atau kombinasi berjalan dan aktifitas fisik intensitas sedang selama tujuh hari dengan minimal 3000 MET-menit/minggu. Kategori minimaly active apabila seseorang melakukan aktivitas fisik intensitas berat selama 20 menit/hari dalam tiga hari atau melakukan aktivitas fisik intensitas sedang/berjalan dilakukan selama 30 menit/hari selama lima hari atau melakukan kombinasi berjalan, aktifitas fisik intensitas sedang dan berat selama lima hari paling sedikit mencapai 600 MET-menit/minggu. Dan kategori inactive apabila seseorang tidak ditemukan pada kategori sedang atau tinggi.

Subjective Happiness Scale (SHS)

Kuesioner ini berisi empat butir pertanyaan yang mengevaluasi kebahagiaan keseluruhan secara subjektif. Kuesioner ini menggunakan skala likert yang terdiri dari skor 1-7. Skor tererendah mengidentifikasikan ketidakbahagiaan sedangkan skor tertinggi mengindetifikasikan kebahagiaan. Total skor tertinggi adalah 28 dan skor terendah adalah empat.

\section{Prosedur}

Penelitian dimulai dengan mengalihbahasakan kuesioner yang akan digunakan ke dalam bahasa Indonesia. Kemudian dilakukan uji keterbacaan kuestioner yang telah pada empat orang dewasa muda untuk mengetahui apakah alat ukur dapat dipahami dengan baik. Pelaksanaan pengumpulan data berlangsung selama bulan Juni 2021. Kuesioner dibagikan melalui google form yang dicantumkan di poster yang disebarkan melalui media sosial. Awal kuesioner berisi inform consent yang menyatakan kesediaan partisipan dalam penelitian. Di dalam poster juga dicantumkan contact person apabila partisipan mengalami kesulitan atau kebingungan pada saat mengisi kuesioner. Pada akhir proses pengambilan data, dibagikan sovernir sebagai tanda terima kasih kepada 20 partisipan yang beruntung.

\section{Analisis data}

Untuk melihat gambaran deskriptif karakteristik demografis, kebahagiaan dan aktivitas fisik digunakan teknik analisis univariat. Selanjutnya untuk melihat hubungan antara tingkat aktivitas fisik dan kebahagiaan

\section{HASIL DAN PEMBAHASAN \\ Karakteristik demografis}

Profesi partisipan dalam penelitian ini yaitu 65,2\% partisipan mahasiswa, $22.6 \%$ partisipan bekerja dan $12.2 \%$ partisipan merupakan IRT dan lainnya. Hasil kuesioner tinggi badan dan berat badan partsipan dijawabkan dalam tabel 1 dibawah. 
Tabel 1. Karakteristik demografis

\begin{tabular}{lrrrrr}
\hline Karakteristik & N & \multicolumn{1}{l}{ Min } & Max & \multicolumn{1}{l}{ Mean } & \multicolumn{1}{l}{ SD } \\
\hline Berat Badan & 115 & $35 \mathrm{~kg}$ & $108 \mathrm{~kg}$ & $55.83 \mathrm{~kg}$ & 12.397 \\
Tinggi Badan & 115 & $147 \mathrm{~cm}$ & $178 \mathrm{~cm}$ & $160 \mathrm{~cm}$ & 7.276 \\
Index Massa Tubuh & 115 & 14.95 & 35.67 & 21.74 & 4.187 \\
\hline
\end{tabular}

Dari hasil olah data didapatkan bawah 9 partisipan memiliki IMT underweight, 72 partisipan memiliki IMT Normal, 18 partisipan memiliki IMT overweight dan 16 partisipan memiliki IMT Obesitas.

\section{Tingkat Aktivitas fisik}

Pada tabel 2, kita dapat melihat tingkat aktivitas fisik dari partisipan. Berdasarkan tabel 2 terlihat bahwa sebagian besar partisipan melakukan aktivitas fisik active minimaly (51.1\%). Seseoarang diklasifikasikan active minimaly apabila selama tiga hari atau lebih dalam seminggu melakukan aktivitas intensitas tinggi dan atau berjalan minimal 30 menit per hari, atau lima hari atau lebih melakukan aktivitas dengan intensitas sedang dan atau berjalan minimal 30 menit per hari, atau lima hari atau lebih melakukan kombinasi berjalan, aktivitas intensitas sedang, atau aktivitas intensitas berat dengan minimal total aktivitas sebesar 600 METS.

Tabel 2 Tingkat aktivitas fisik

\begin{tabular}{lrr}
\hline Tingkat Aktivitas Fisik & N & Persentase \\
\hline Inactive & 19 & $16.5 \%$ \\
Active Minimaly & 68 & $51.1 \%$ \\
Hepa Active & 28 & $24.3 \%$ \\
\hline Total & $\mathbf{1 1 5}$ & $\mathbf{1 0 0 \%}$ \\
\hline
\end{tabular}

Pada tabel 3, dapat disimpulkan bahwa sebagian besar partisipan merasa bahagia (38.3\%) dan sering bahagia $(27.8 \%)$.

Tabel 3 Kebahagiaan

\begin{tabular}{lrr}
\hline Tingkat kebahagiaan & N & Persentase \\
\hline Tidak bahagia & 6 & $5.2 \%$ \\
Agak bahagia & 17 & $14.8 \%$ \\
Bahagia & 44 & $38.3 \%$ \\
Sering Bahagia & 32 & $27.8 \%$ \\
Sangat Bahagia & 16 & $13.9 \%$ \\
\hline Total & $\mathbf{1 1 5}$ & $\mathbf{1 0 0 \%}$ \\
\hline
\end{tabular}

Selanjutnya dilakukan analisis pearson test, didapatkan hasil $0.108<0.183, \mathrm{p}=0.05$ sehingga maka H0 ditolak. Meskipun demikian hasil analisis analisis stastistik compare mean (tabel 4), didapatkan bahwa seseorang dengan tingkat aktivitas hepa active memiliki tingkat kebahagaiaan rata-rata lebih tinggi dibandingkan dengan partisipan dengan tingkat aktivitas inactive dan active minimaly.

Tabel 4 tingkat aktivitas fisik dengan kebahagiaan

\begin{tabular}{lrrr}
\hline IPAQ & SHS Mean & N & \multicolumn{2}{c}{ SD } \\
\hline Inactive & 20.32 & 19 & 3.163 \\
Active minimaly & 20.57 & 68 & 4.575 \\
Hepa active & 21.86 & 28 & 4.495 \\
\hline
\end{tabular}




\section{Diskusi}

\begin{tabular}{llll}
\hline Total & 20.84 & 115 & 4.360 \\
\hline
\end{tabular}

Berdasarkan hasil dari penelitian yang dilakukan didapatkan bahwa sebagian besar partisipan memiliki tingkat aktivitas fisik pada dewasa muda selama pandemi covid-19 didapatkan hasil minimaly active. Hal ini ditunjang dengan systematic riview yang dilakukan Suryoadji dan Nugraha (2021) mendapatkan hasil bahwa sebagian besar partisipan mengalami pengurangan aktivitas fisik semenjak adanya pandemi covid-19. Penelitian yang dilakuakn Wungow, Berhimpong, dan Telew (2021) di manado mendapatkan hasil bahwa 47,9\% partisipan memiliki tingkat aktivitas fisik inactive, 38,9\% melakukan tingkat aktivitas fisik minimaly active dan hanya 13,3\% melalukan aktivitas fisik hepa active. Condrowati dan Bachtiar (2020) mendapatkan hasil bahwa sebagian besar partisipan menunjukankan tingkat activitas minimaly activity, hal ini disebabkan karena mayoritas partisipan menghabiskan 4 - 6 jam bekerja dalam posisi duduk selama WFH sehigga mereka memiliki lebih sedikit kesempatan untuk berpartisipasi dalam aktivitas fisik.

Sebaian besar partisipan merasa bahagia dan sering bahagia. Hal sesuai dengan penelitian Bhatpahari (2021) mendapatkan hasil bahwa sebagian besar partisipannya menyatakan kebahagiaan yang cukup karena dengan melakukan selama PPKM karena dapat tetap melakukan pekerjaan di rumah, masih bisa produktif, serta mendapatkan waktu luang yang cukup untuk kesimbangan kehidupan kerja dan keluarga. Rahmanita, dkk (2021) menambahkan bahwa kondisi PPKM menyebabkan para responden dapat melakukan berbagai aktivitas rekreasi di rumah seperti berolahraga, berkebun, berjemur, dan melakukan beraktivitas di sekitar kompleks perumahan seperti berjalan santai, bersepeda, jogging. Meskipun demikian tingkat kebahagiaan dewasa muda cendung pada level menengah, hal ini sesuai dengan penelitian Twenge, Sherman, dan Lyubomirsky (2015) yang menyatakan bahwa tingkat kebahagiaan didapatkan lebih tinggi pada orang yang lebih mudah dibandingkan dengan orang yang lebih dewasa.

Berdasarkan data penelitian menunjukan tidak ada hubungan signifikan antara tingkat aktivitas fisik dengan kebahagiaan, hal ini mungkin disebabkan karena jumlah partisipan yang sedikit dan tidak merata. Meskipun demikian tingkat kebahagiaan meningkat sejalan dengan tingkat aktivitas fisik. Hal ini sesuai dengan systematic riview dari limabelas artikel yang dilakukan oleh Zhanjia Zhang dan Weiyun Chen (2018) yang menemukan hubungan positif antara aktivitas fisik dan kebahagiaan. Aktivitas fisik telah terbukti meningkatkan transmisi neurotransmitter (noradrenalin, dopamin, dan serotonin) di otak dan meningkatkan produksi endorfin. Komponen tersebut berfungsi dalam menurunkan tingkat stress dan endorfin berfungsi untuk meningkatkan kebahagiaan (Suparno, 2007; Pilozzi, Carro, \& Huang, 2021). Selain itu, kebahagiaan memberikan efek yang dijelaskan dalam Theory of Planned Behavior yang mempengaruhi niat untuk terlibat dalam aktivitas fisik dan pengalaman afektif yang diantisipasi memprediksi perilaku aktivitas fisik di masa depan (van Woudenberg, 2020).

\section{PENUTUP}

Bebagai yang dilakukan membutikan bahwa kebahgiaan meningkat sejalan dengan meningkatnya aktivitas fisik. Meskipun demikian penelitian ini belum menunjukan hasil korelasi yang signifikan, Oleh sebab itu dapat dilakukan penelitian-penelitian lanjutan dengan skala yang lebih besar mengenai hubungan antara kebahagiaan dengan tingkat aktivitas fisik. Pada penelitian ini, peneliti menggunakan partisipan dengan rentang usia dewasa muda, yang menunjukan 
mendapatkan kebahagiaan melalui berbagai aktivitas rekreasi di rumah seperti berolahraga, berkebun, berjalan santai, bersepeda, dan jogging.

\section{DAFTAR PUSTAKA}

Bhatpahari, G. (2021). Amidst COVID-19 Happiness: A key indicator of Mental Health. international Journal of All Research Education and Scientific Methods (IJARESM), ISSN: 2455-6211. Vol 9, Issue 3,7.429. Retrieved from http://www.ijaresm.com/uploaded_files/document_file/Dr._Gautami_Bhatpahari_PzB4.pdf

Chinni M. (2014) Subjective Happiness Scale. In: Michalos A.C. (eds) Encyclopedia of Quality of Life and Well-Being Research. Springer, Dordrecht. Retrieved from https://doi.org/10.1007/978-94-007-0753-5_2898

Cho M.S., Kim J.Y. (2019). A study of factors affecting the physical activity of youth: Analysis of data from the 13th youth health behavior online survey in 2017. J Exerc Rehabil. 15(1):814. doi: $10.12965 /$ jer. 1836616.308

Condrowati \& Bachtiar, F. (2020). Physical Activity Levels of Adults During Covid-19 Quarantine in Indonesia: A Cross-Sectional Descriptive Study. Conference: International Conference of Health Development. Covid-19 and the Role of Healthcare Workers in the Industrial Era (ICHD 2020). DOI:10.2991/ahsr.k.201125.047

Hamka, A.S., Yuniarti, K. W., Moordiningsih \& Kim, U. (2015). Who Makes Adolescents Happy ? an Explorative Study Using The Indigenous Physhology Approach. Jurnal Indigenous Vol. 13, No. 2, 19-32. Retrieved from https://journals.ums.ac.id/index.php/indigenous/article/view/2599/1707

Heydenreich J., Kayser B., Schutz Y., Melzer K. (2017). Total Energy Expenditure, Energy Intake, and Body Composition in Endurance Athletes Across the Training Season: A Systematic Review. Sport Med - Open. 3(1):1-24. DOI: 10.1186/s40798-017-0076-1

Ilpaj S.M., Nurwati N. (2020) Analisis Pengaruh Tingkat Kematian Akibat Covid-19 Terhadap Kesehatan Mental Masyarakat Di Indonesia. Focus J Pekerj Sos. 3(1):16. Retrieved from https://jurnal.unpad.ac.id/focus/article/view/28123

Lee E.Y., An K., Jeon J.Y., Rodgers W.M., Harber V.J., Spence J.C. (2016). Biological Maturation and Physical Activity in South Korean Adolescent Girls. Med Sci Sports Exerc. 48(12):2454-61. Retrieved from https://jurnal.unpad.ac.id/focus/article/view/28123

Lyubomirsky, S., \& Ross, L. (1999). Changes in attractiveness of elected, rejected, and precluded alternatives: A comparison of happy and unhappy individuals. Journal of Personality and Social Psychology, 76, 988-1007. doi: 10.1037//0022-3514.76.6.988.

Pecanha T., Goessler K.F., Roschel H., Gualano B. (2020) Social isolation during the COVID-19 pandemic can increase physical inactivity and the global burden of cardiovascular disease. Am J Physiol - Hear Circ Physiol. 318(6):H1441-6. doi: 10.1152/ajpheart.00268.2020.

Physical Activity and Your Heart | NHLBI, NIH [Internet]. Available from: https://www.nhlbi.nih.gov/health-topics/physical-activity-and-your-heart

Pilozzi, A., Carro, C. \& Huang, X. (2021).Review Roles of $\beta$-Endorphin in Stress, Behavior, Neuroinflammation, and Brain Energy Metabolism. Int. J. Mol. Sci. 22, 338. https://doi.org/10.3390/ijms22010338.

Rahmanita, M., Nurbaeti, Asmaniati, F., Dewi, T.R., \& Widyastuti, N. (2021). Covid-19 Pandemic: Happiness Revisited through Work and Leisure During the Stay at Home Period. 
Journal of Hunan University (Natural Sciences) Vol. 48. No. 4. Retrieved from: http://jonuns.com/index.php/journal/article/view/543

Seefeldt V, Malina RM, Clark MA. (2002). Factors Influencing Levels of Physical Activity in Adults. Sport Med. 32(3):143-68. Retrieved from : https://link.springer.com/content/pdf/10.2165\%2F00007256-200232030-00001.pdf

Suparno. (2007). Pengaruh Stresor Psikologik Terhadap Distribusi Transporter Serotonin (Sert) dan Indeks Apoptosis Hipokampus Yang Dimediasi Oleh Kortisol Dan IL - 6. Jurnal Kedokteran Brawijaya, Vol. XXIII, No. 3. https://doi.org/10.21776/ub.jkb.2007.023.03.1

Suryoadji, K.A. \& Nugraha, D.A. (2021). Aktivitas Fisik Pada Anak Dan Remaja Selama Pandemi Covid-19: A Systematic Review. Khazanah : Jurnal Mahasiswa Volume 13 Nomor 1 P-ISSN : 1979519X E-ISSN : 27458733. Retrieved from :

https://journal.uii.ac.id/khazanah/article/view/19939

Twenge, J. M., Sherman, R.A., Lyubomirsky, S. (2015). More Happiness for Young People and Less for Mature Adults: Time Period Differences in Subjective Well-Being in the United States, 1972-2014. Social Psychological and Personality Science 7(2). DOI:10.1177/1948550615602933

van Woudenberg, T.J., Bevelander, K.E., Burk, W.J. et al. (2020) The Reciprocal Effects of Physical Activity and Happiness in Adolescents. International Journal of Behavioral Nutrition and Physical Activity 17, 147. Retrieved from: https://doi.org/10.1186/s12966020-01058-8

WHO - Physical activity.

Westerterp KR. (2013). Physical Activity and Physical Activity Induced Energy Expenditure in Humans: Measurement, Determinants, and Effects. Front Physiol. 1-11. doi: 10.3389/fphys.2013.00090.

Wungow, L., Berhimpong, M., \& Telew, A. (2021). Tingkat Aktivitas Fisik Mahasiswa Program Studi Ilmu Kesehatan Masyarakat Universitas Negeri Manado Saat Masa Pandemi Covid19. PIDEMIA Jurnal Kesehatan Masyarakat UNIMA Vol.02, No.03. Hal 22-27. ISSN Online : 2774-6909. Retrieved from : https://media.neliti.com/media/publications/348850tingkat-aktivitas-fisik-mahasiswa-progra-ca1030ac.pdf

ZhanjiaZhang \& Weiyun Chen. (2018). A Systematic Review of the Relationship Between Physical Activity and Happiness. J Happiness Stud. https://doi.org/10.1007/s10902-0189976-0 